\title{
側壁・底面粗度の相違が第一種二次流に与える 影響に関する数值実験的検討 \\ NUMERICAL STUDY ON EFFECT OF DIFFRENCE BETWEEN SIDE WALL AND BOTTOM WALL ROUGHNESS COEFFICIENTS ON SECONDARY FLOW IN BEND CHANNEL
}

\author{
八軒啓彰 1 ・朝位孝二 $2 \cdot$ 渡辺勝利 3 \\ Hiroaki HACHIKEN, Koji ASAI and Katsutoshi WATANABE \\ 1学生会員 山口大学大学院 理工学研究科博士前期課程 社会建設工学専攻 \\ （广755-8611 山口県宇部市常盤台2-16-1） \\ 2正会員 博士（工） 山口大学教授 大学院理工学研究科（同上） \\ 3 正会員 博士（工） 徳山工業高等専門学校教授 土木建築工学科（テ745-8585 山口県周南市学園台）.
}

In this study, we conducted numerical experiments to investigate the influence of the wall and bed roughness to the secondary flow in a bend part in open channel flows. The nays CUBE distributed by the iRIC project was used in this study. Firstly we conformed that the nays CUBE has good accuracy to predict the three dimensional flow by comparing with our laboratory experimental data.

We conducted numerical experiments under the five cases. In the cases that the wall roughness is smaller than or equal to the bed roughness, the circulation near the inner bank wall became bigger as the side wall roughness increased in the entrance of the bend part. On the other hand, in the cases that the wall roughness is greater than the bed roughness, the circulations near the outer bank wall were not clear at the middle of the bend part.

Key Words : Numerical experiment, bend flow, iRIC, roughness, secondary flow

\section{1. はじめに}

洪水時の河川において最も危惧されるべき問題は堤防 の決壊や越流による汇濫である. 特に河川の蛇行部は遠 心力に起因寸る強い螺旋流が生じ，これが護岸や護岸の 根固めを破壊することが良く知られている。このため, 蛇行部の水理については実験的にも数值計算的にも多く 研究が行われている.

主流方向に直交する断面内において発生している流れ は二次流と呼ばれるが，その生成要因にしたがってプラ ントルは二次流を二種類に分類している. 遠心力に起因 する螺旋流はプラントルの第一種二次流と呼ばれ，直接 の外力を持たずに直線部においても発生し得るものはプ ラントルの第二種二次流と呼ばれる. 第二種二次流は乱 れの非等方性から発生しており，その大きさは主流の 数\%程度しかないといわれている. 一方, 第一種二次流 は流路の湾曲の緩急により大きく変動し主流の $20 \%$ 以上 となるケースもあるため，河川防災を考える上で無視す
ることは出来ない．第一種二次流に関する問題は河川工 学における古典的な問題として広く認識され，そのメカ ニズムや河床変動などに及ぼす影響について, 従来から 多くの研究が進められてきている．湾曲部の水面付近の 流速分布に着目寸ると, 第一種二次流の効果は水面付近 の高速流体塊を遠心力方向に押しやるため, 最大流速の 生じる横断方向の位置を, 外岸側にシフトする効果があ るといわれている1)。

河川防災上，二次流を制御することが重要である。例 えば，水制あるいはベーン工などの設置による二次流の 制御が試みられている2). 水制は水跳ね作用により流れ の方向を変え，ベーン工は二次流を直接制御する．一方 で側壁や底面の粗度を変えて制御寸ることも考えられる. 蛇行流路の三次元数值解析は, 例えば杉山ら ${ }^{4}$ の研究が あるが，側壁面，底面の粗度は同一としている，底面と 側壁の粗度が異なる開水路の研究として, Naot' の相違が第二種二次流に与える影響について数值計算を 用いて検討した。 また，Tominaga $ら^{6}$ ， Hayashiら ${ }^{7)}$ も側 壁，底壁の粗度による主流速および二次流への影響を実 


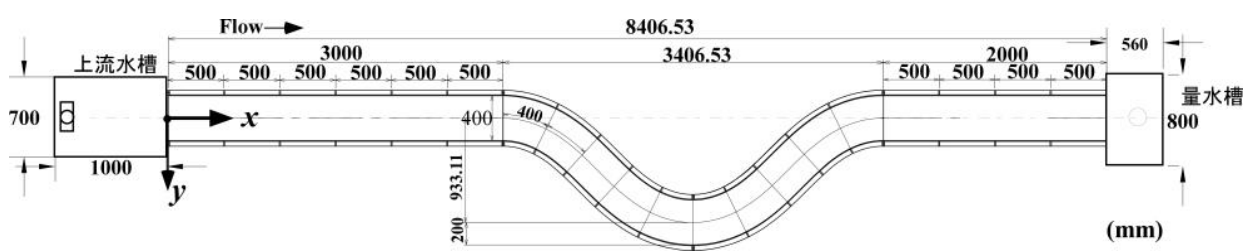

図-1＼cjkstart実験水路の平面図

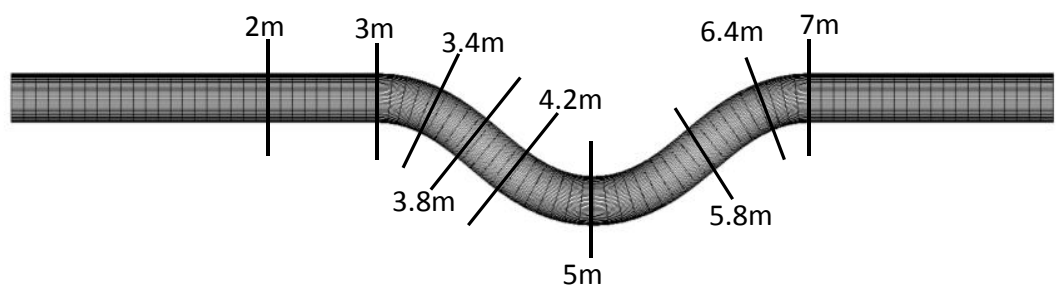

図-2 計算格子

表-1＼cjkstart計算格子の諸元

\begin{tabular}{|l|c|c|c|}
\hline & 上流側直線部 & 蛇行部 & 下流側直線部 \\
\hline 水路長距離 & $3 \mathrm{~m}$ & $4 \mathrm{~m}$ & $2 \mathrm{~m}$ \\
\hline 流下方向格子数 & 30 & 40 & 20 \\
\hline 横断方向格子数 & 40 & 40 & 40 \\
\hline 流下方向格子幅 & $0.1 \mathrm{~m}$ & $0.1 \mathrm{~m}$ & $0.1 \mathrm{~m}$ \\
\hline 横断方向最小格子幅 & $0.005 \mathrm{~m}$ & $0.005 \mathrm{~m}$ & $0.005 \mathrm{~m}$ \\
\hline 横断方向最大格子幅 & $0.015 \mathrm{~m}$ & $0.015 \mathrm{~m}$ & $0.015 \mathrm{~m}$ \\
\hline
\end{tabular}

験的に検討しているが，これらはいずれも直線形状の流 路における検討に留まっている.

以上を踏まえて，本研究では蛇行開水路において底面 と側壁の粗度係数を変えた場合の数值解析を行い，粗度 の差が第一種，第二種二次流の双方に与える影響につい て検討することを目的とする.

\section{2. 数値解析法と数值計算結果の実験值との比較}

\section{(1) 数值解析ソルバー}

本研究では三次元解析を行うため河川解析共通プラッ トフォームであるiRIC ${ }^{4}$ のNaysCUBE ver3.20.1を使用し た. NaysCUBEでは一般座標系における非圧縮性流体の

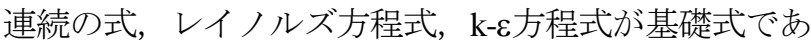
る。その詳細は既往論文1)，8)を参照されたい．乱流モデ

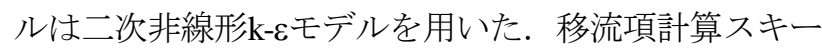
厶, 離散化手法, 時間積分法, 圧力・速度緩和法は文献 1), 6) と同様である.

\section{（2）実験水路と計算格子}

計算モデルの妥当性を検討するため実験值との比較を 行った. 図-1に実験水路の平面図を示す。この水路は直 線水路の中に正弦関数型の蛇行部が設けられている. 上 流部直線水路の長さは $3 \mathrm{~m}$, 下流部直線水路の長さは2m,

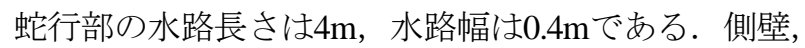
底面とも全てアクリルガラスで製作されている. 水路床 勾配は0である。供給流量は $0.01 \mathrm{~m}^{3} / \mathrm{sec}, て ゙$ 全体的に水路

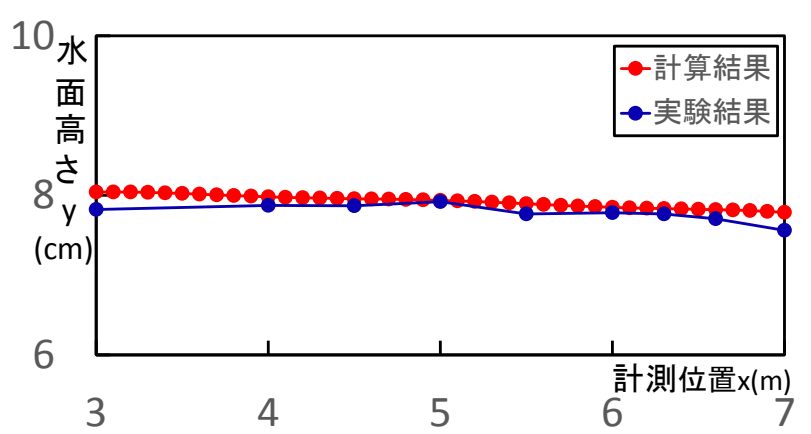

図-3 水面形の縦断方向分布

中央部の水深が $0.08 \mathrm{~m}$ 程度となるように下流側の水深を 調節した。下流端水深は $0.08 \mathrm{~m}$ である。水路中央部を原 点として右岸方向に $y$ 座標をとり, 水路に沿った流下方 向を $x$ 座標とする.

図-2に数值計算で使用した計算格子を示す。水路中央 部から側壁に向けて等差数列を用いて格子を形成してい る.また鈶直方向には16層に分割した．計算格子の諸元 を表-1に示す。困中の断面の位置は後述の計算結果を示 す断面である，水深はポイントゲージで，流速は電磁流 速計（KENEK社 VP2500/VPT-200-08PS）で計測された. これは流下方向と横断方向の2成分の流速計である.

\section{(3) 計算条件}

初期条件は静止の状態で，一定水深 $0.08 \mathrm{~m}$ をえた。 上流端境界条件として一定流量 $0.01 \mathrm{~m}^{3} / \mathrm{sec}$ をえ，下流 端境界条件として，水深 $0.075 \mathrm{~m}$ 与えた。水路床勾配は 0であるので水深がそのまま水位と考えてよい.

NaysCUBEでは，底面と側壁に抵抗則としてマニング 式が用いられている. 一般的にアクリル板のマニングの 粗度係数は0.0090〜0.010であるので，底面，側壁ともに 0.010を与えた。計算は後述するように側壁と底面の粗 度係数を変えた場合も行っているが，いずれも初期条件 から40秒程度で変化が小さくなり，50秒から60秒で定常 となった. 以下に示す計算結果はすべて60秒での結果を 示している. 


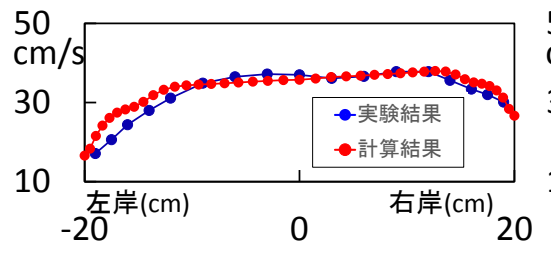

(a) $z=7 \mathrm{~cm}$

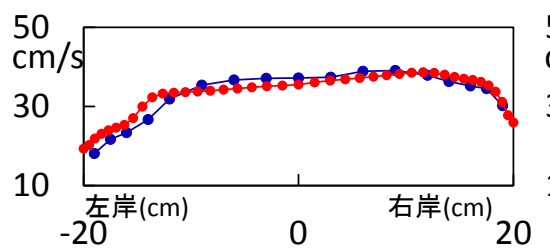

(a) $z=7 \mathrm{~cm}$

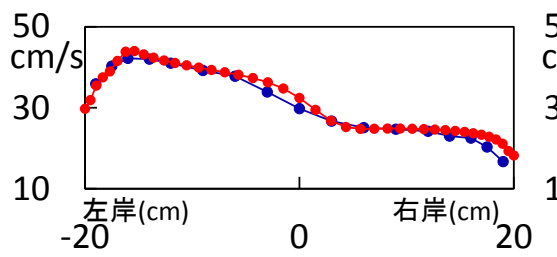

(a) $\mathrm{z}=7 \mathrm{~cm}$

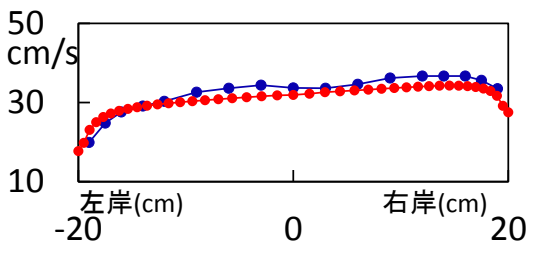

(b) $z=3 \mathrm{~cm}$

(1) $x=3.0 \mathrm{~m}$

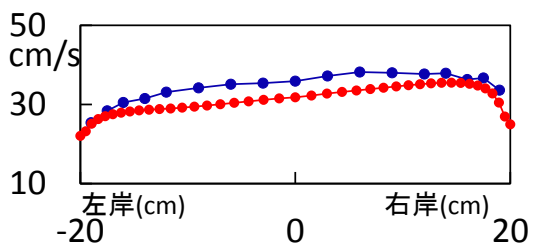

(b) $z=3 \mathrm{~cm}$

(2) $x=3.4 m$

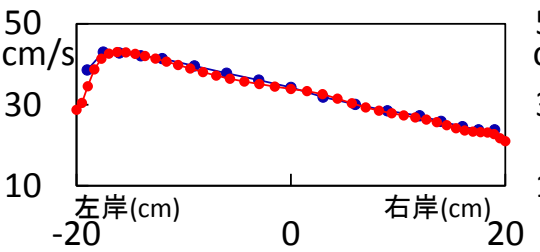

(b) $z=3 \mathrm{~cm}$

(3) $x=5.0 \mathrm{~m}$

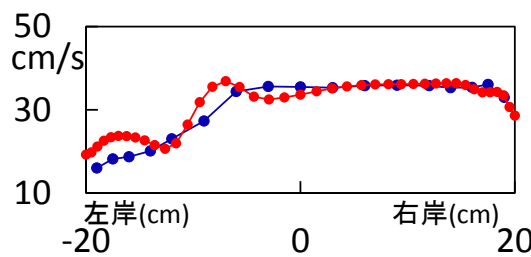

(a) $\mathrm{z}=7 \mathrm{~cm}$

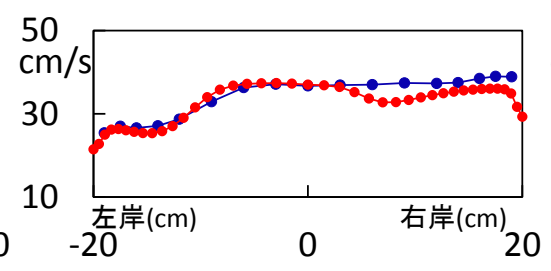

(b) $z=3 \mathrm{~cm}$

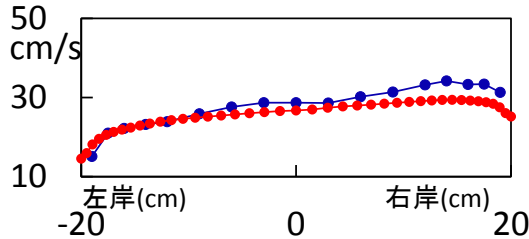

(c) $z=1 \mathrm{~cm}$

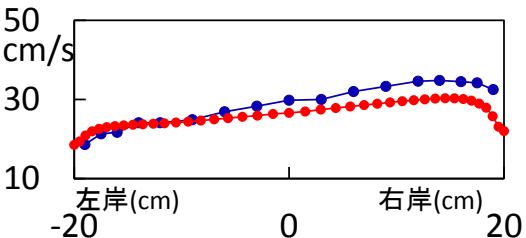

(c) $z=1 \mathrm{~cm}$

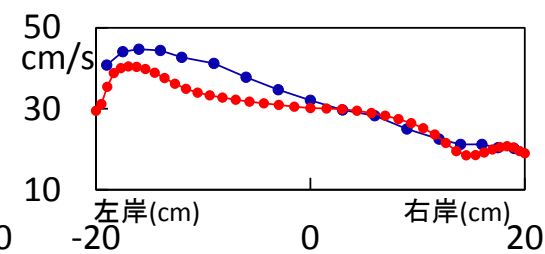

(c) $\mathrm{z}=1 \mathrm{~cm}$

(4) $X=6.4 m$

図-4 主流速の横断方向分布

\section{(4) 水面形の縱断方向分布}

図-3に水面形の縦断方向分布を示寸．比較対象は水路 中央部 $(y=0)$ の蛇行部開始点 $(x=3.0 \mathrm{~m})$ から蛇行部終了点 $(x=7.0 \mathrm{~m})$ までである，青色の線が実験值を，赤色の線が 計算值を表している．計算結果と実験結果は厳密に見れ ば2〜 3mm程度の不一致はあるが，概ね良好な計算結果 を示している.

\section{（5）主流速の横断方向分布}

図-4に主流速の横断方向分布を示す．青色の線が実験 值で赤色の線が計算值である。またzは底面を原点とし て鉛直上向きを正とする座標である， $z=7 \mathrm{~cm}, 3 \mathrm{~cm}$, $1 \mathrm{~cm}$ はそれぞれ表層, 中層, 低層の位置である.

$x=3.0 \mathrm{~m}$ の断面は蛇行部の前面であるが，蛇行部の影響 がすでに現れており，右岸側の流速が若干速くなってい る. 全層とも, 実験值と計算值は良い一致を見ている. $x=3.4 \mathrm{~m}$ 断面では全層にわたつて右岸側に最大流速が 現れている，表層での再現性は良好であるが，中層，低 層では若干実験值よりも計算值は小さくなっている.

$x=5.0 \mathrm{~m}$ の断面は蛇行部の頂点に位置する. 最大流速は 左岸側に現れている，計算值と実験值は表層と中層にお いては良い一致が見られるが，低層では水路中央部から 左岸側で実験值よりも小さくなっている．しかながら定 性的には実験值と一致している.

$x=6.4 \mathrm{~m}$ の断面では最大流速は再び右岸側に現れている. 表層における計算值は実測值と良く一致しているが，中 層，低層では計算值は実測值よりも若干小さくなってい る.しかしながら右岸側に向かって流速が大きくなる傾 向は良く再現されている.

計算值は多少実験值と異なる性状を示す場合も見受け られるが，全体的には計算值は実験值に対して良好な再 現性を持っていた. NaysCUBEは水平水路においても十 


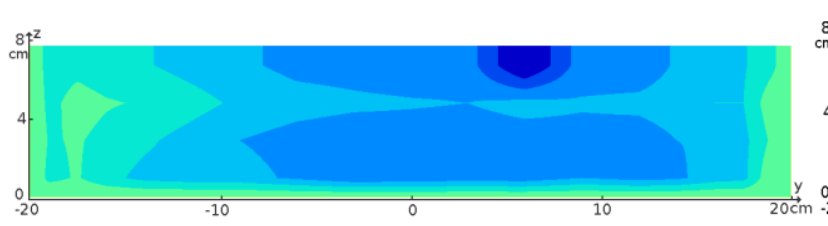

（1）実験値 $(x=3.0 \mathrm{~m})$

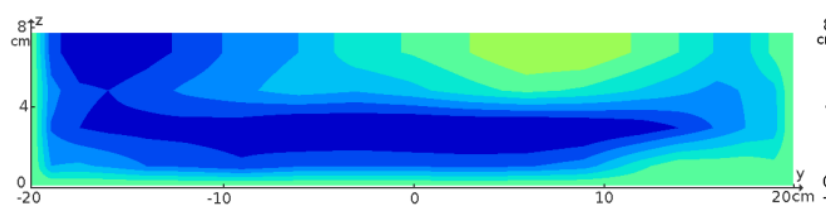

（3）実験値（ $x=5.0 m)$

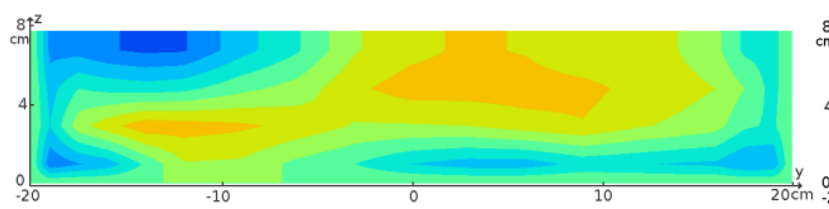

（5）実験値 $(x=7.0 m)$

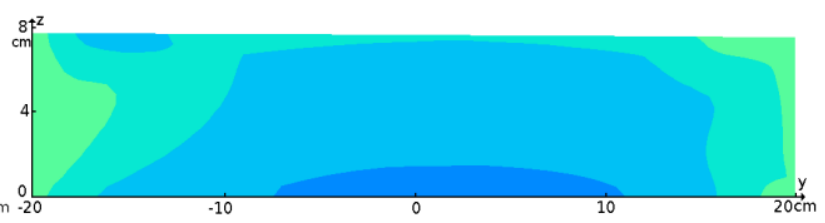

(2) 計算値 $(x=3.0 \mathrm{~m})$

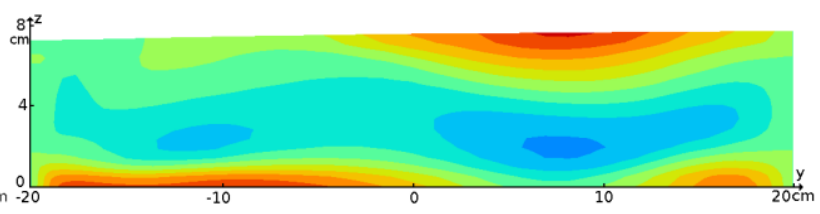

（4）計算値 $(x=5.0 \mathrm{~m})$

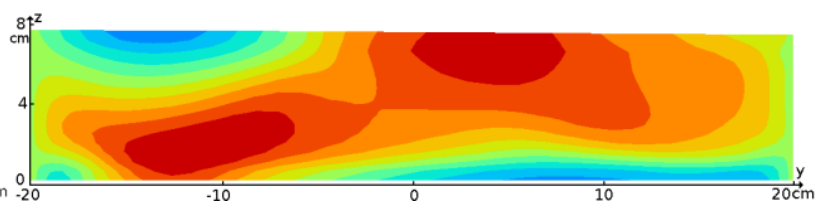

(6) 計算値 $(x=7.0 \mathrm{~m})$

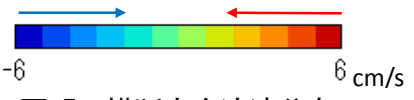

図-5 横断方向流速分布

表-2 側壁と底面の粗度の条件

\begin{tabular}{|c|c|c|}
\hline Case & 側壁粗度 & 底面粗度 \\
\hline $\mathbf{A}$ & 0.01 & 0.01 \\
\hline $\mathbf{B}$ & 0.015 & 0.01 \\
\hline $\mathbf{C}$ & 0.02 & 0.01 \\
\hline $\mathbf{D}$ & 0.01 & 0.015 \\
\hline $\mathbf{E}$ & 0.01 & 0.02 \\
\hline
\end{tabular}

分対応可能であることが確認できた.

\section{(6) 横断方向流速}

湾曲水路ではプラントルの第一種二次流が生じるため, 数值計算においても精度良く二次流が再現できているか を検討する必要がある。しかしながら実験で用いた電磁 流速計では二次流成分としては横断方向流速しか計測で きない. そのためここでは横断方向（y方向）流速の断 面分布の比較を行う。その結果を図-5に示す。本図にお いて暖色系の色は左岸方向に向かう流速を, 寒色系の色 は右岸方向に向から流速を表す。

$x=3.0 \mathrm{~m}$ の断面では横断方向流速は小さい, したがって 第二種二次流は存在しているものの，第一種二次流はま だ発達していない. $x=5.0 \mathrm{~m}$ の断面における実験值では 底面近傍では右岸に向から流速が存在し, 水面近傍の $y=0.0 \sim 0.1 \mathrm{~m}$ 付近では左岸に向から流速が存在している. 計算值においても同様の傾向を示していることがわかる. $x=7.0 \mathrm{~m} の$ 断面における実験值では左岸側水面近傍と水路 中央部から右岸側の底面近傍を除いて，左岸向きの流れ が生じている．計算值も同様の傾向を示しているが，全 体的に実験結果の方が右岸向きの流速が大きく，計算結 果の方が左岸向きの流速が大きくなっている様子が確認 できることから，定量的には若干相違があるようである.
横断方向流速においても計算值は実験值を定性的には 良く再現できている．定量的には一致していないところ もあるが，概ね二次流の横断方向成分を再現できている ものと思われる.

\section{3. 側壁と底面の粗度係数の比較}

\section{（1）二次流ベクトルと主流速分布}

この章では側壁と底面のマニングの粗度係数を種々変 えて二次流のパターンがどのように変わるのかを検討す る. 表-2に数值実験のケースを示す．Case-A，B，Cは 底面粗度を固定して側壁粗度を大きくした場合である. また，これらは底面粗度が側壁粗度よりも小さいか等し い場合である. Case-D，Eは側壁粗度を固定して底面粗 度を大きくした場合で，底面粗度が側壁粗度よりも大き い. Case-Aは実験水路と同じ粗度係数であるので, この 計算結果を基本として他のケースを検討していく.

$x=3.0 \mathrm{~m}$ は蛇行部手前の断面である。いずれのケースも 左岸から右岸に向から流れが卓越しており，顕著な螺旋 流的な流れは生じていない.しかし, Case-B, Case-Cで は右岸側壁近傍の水面付近で微小な循環が生じている. また主流速の最速部はいずれのケースにおいても，二次 流によって若干右岸側にシフトされているようではある が，全体的には中央部に最速部が残っている.

$x=3.4 \mathrm{~m}$ ではいずれも全体的に反時計回りの大きな循環 流が生じている.また左岸側壁近傍の水面付近では時計 回りの補償的な循環流が見受けられる.この循環流は Case-A， B，Cの順で大きくなっていることが分かる.

これらケースでは底面粗度は同一であるので，側壁粗 

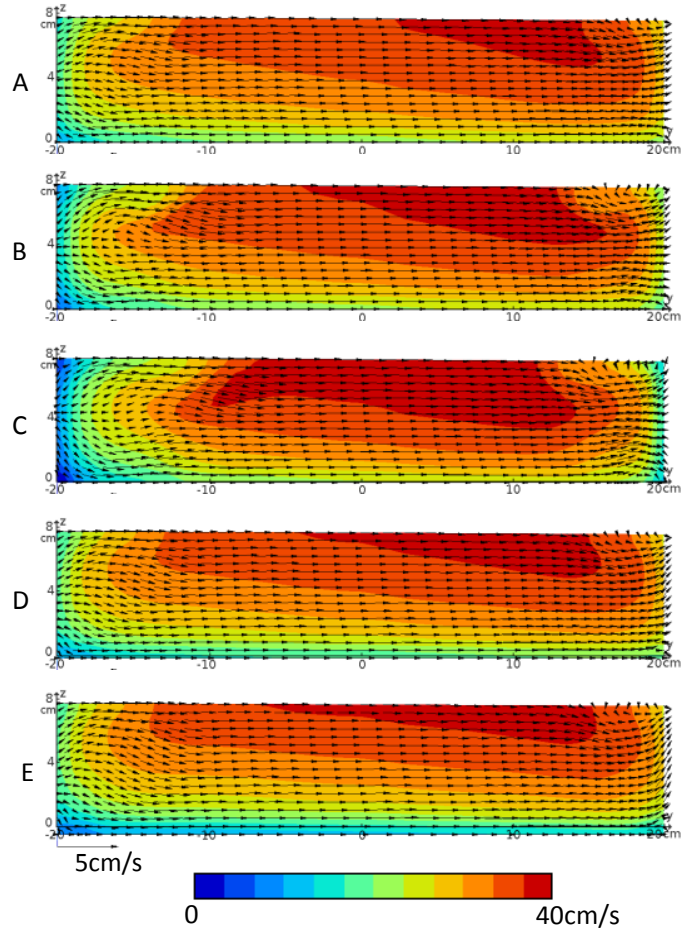

(a) $x=3.0 \mathrm{~m}$
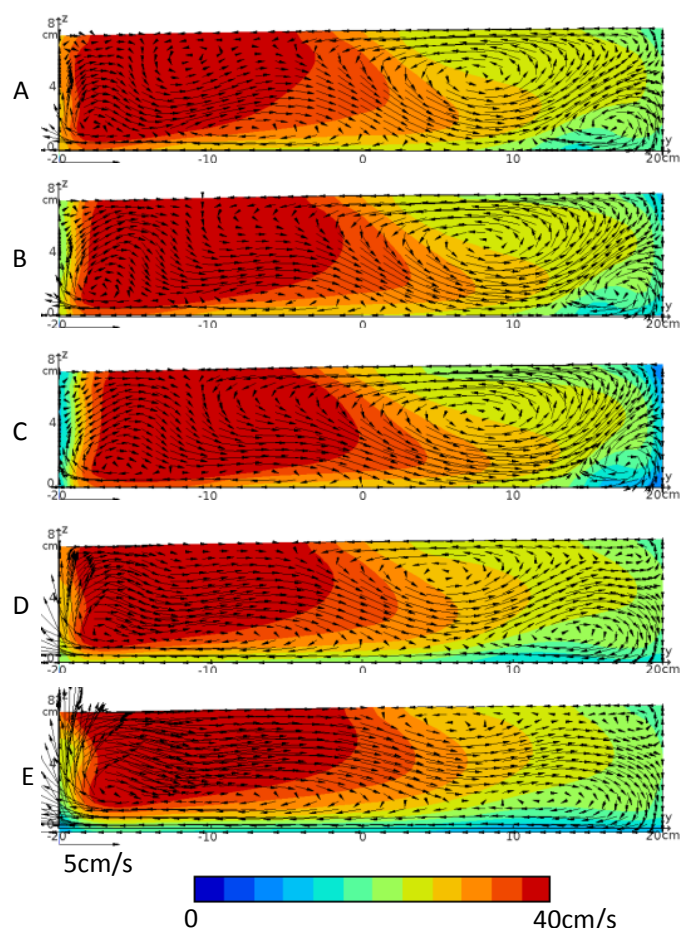

(c) $x=5.0 \mathrm{~m}$
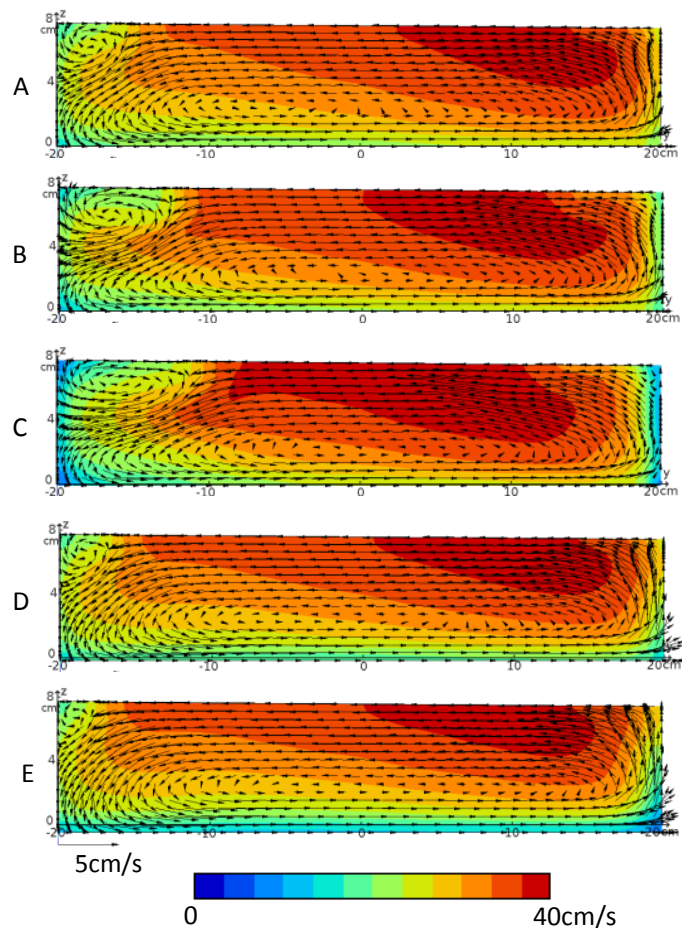

(b) $x=3.4 \mathrm{~m}$
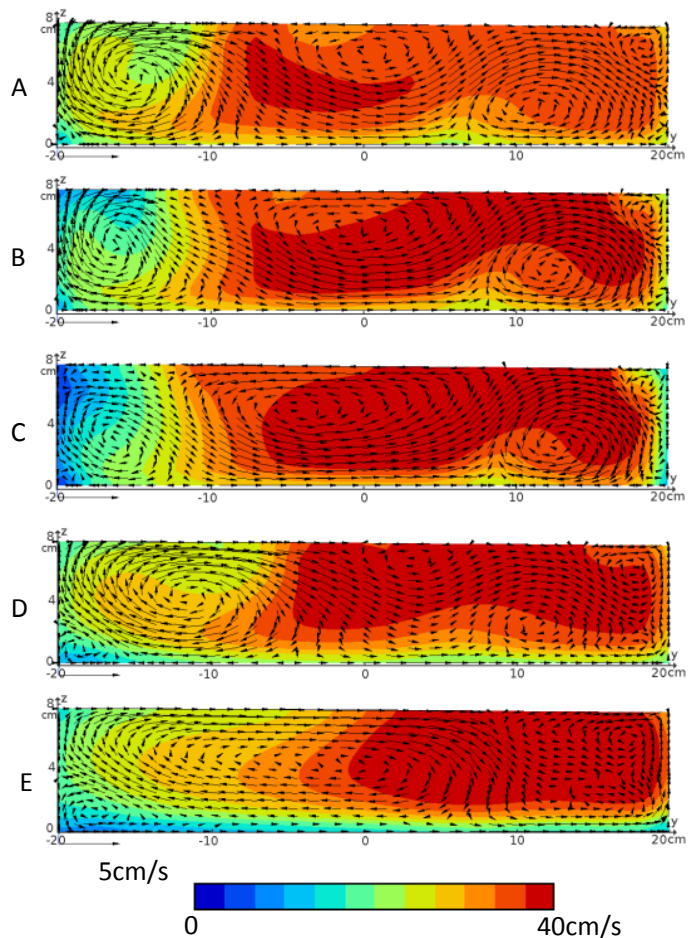

(d) $x=6.4 m$

図-6 二次流ベクトルと主流速分布

度が大きいほど循環流も大きくなっていることが分かる 一方でCase-A，B，Cとは逆に底面粗度の方が側壁粗度 よりも大きいCase-D，Eでは，この循環流は逆に側壁粗 度が大きいほど小さくなってしまう。また最大流速の部 分は右岸側に現れており，二次流ベクトルで最大流速が 左岸側に輸送されていることが分かる.

$x=5.0 \mathrm{~m}$ ではいずれも最大流速の部分が左岸に現れてい る。またCase-Eを除いて水路中央部から右岸側壁におい
て反時計回りの大きな循環流が生じている，右岸側壁の 底面付近ではこの循環流を補償する時計回りの循環流が 現れている．Case-A，B，Cを見ると，この循環流は側 壁近傍であるため側壁粗度が大きくなるにつれて小さく なっていくことが分かる．一方でCase-AとDを比較する と側壁粗度は同じであっても底面粗度が大きくなると， この循環流は大きくなり, 水路中央部の反時計回りの循 環流の規模が小さくなることが分かる．また，Case-D， 
Eでは，左岸側壁に沿う上昇流的流れが強くなっている Case-Eでは半水深位置に左岸から右岸に向から流れがそ のまま右岸側壁に衝突して上昇流と下降流に分離してい る. 顕著な大規模循環流が見られない.

$x=6.4 \mathrm{~m}$ ではいずれも最大流速は再び右岸側に現れてい る. 特徵的な循環流として左岸側壁近傍の時計回りの流 れと右岸側壁近傍の時計回りの流れが挙げられる. 左岸 側の循環流は側壁粗度が大きくなるCase-A，B，Cの順 で小さくなっている．また，Case-D， Eでは底面粗度が 大きくなるほど左岸側の循環流が大きくなっている，右 岸側の循環流もCase-A，B，Cの順で小さくなっている. 一方, Case-D，Eでは時計回りの循環よりも，右岸水面 近傍の反時計回りの渦が顕著である. 水路中央部には反 時計回りの循環流が存在しているが，これはCase-A，B， Cの順で両側壁の渦が小さくなるにつれて，中央部の循 環流が大きくなっていく。しかしながらCase-D，Eでは この中央部の循環流が小さく特に, Case-Eでは左岸側の 循環流が支配的なため, ほとんど消滅している.

\section{（2）水深平均流速の平面図}

図-6には水深平均流速の平面分布を示している．滝本 ら9) は曲率が一定の湾曲水路で最大流速が現れる場所を 検討している. 彼らは緩湾曲水路では最大流速が外岸側 に現れ，急湾曲水路では最大流速が内岸側に生じてやが て外岸側に移動することを示した，本計算結果ではいず れのケースにおいても $x=3.4 \mathrm{~m}$ 近傍から内岸側の流速が早 くなり, 蛇行部頂点を過ぎたところから最大流速は水路 中央部に現れる.

\section{4. おわりに}

本研究では側壁と底面の粗度係数が蛇行部に発生する 第一種二次流にどのような影響を与えるのかを検討する 目的で数值実験を行った，その結果，底面粗度が側壁粗 度よりも小さいか等しい場合（Case-A，B，C）の結果 を比較すると, 蛇行部進入直後では, 側壁粗度が大きく なるにつれ内岸側の循環流も大きくなることがわかった しかし, 底面粗度が側壁粗度よりも大きい場合その効果 は逆転する.

底面粗度が側壁粗度よりも小さいか等しい場合蛇行部 頂点では外岸側底面部の循環流が側壁粗度が大きいほど 小さくなる，一方，底面粗度が側壁粗度よりも大きい場 合, 外岸側壁近傍では顕著な循環流が存在しなくなる. さらに流下寸ると，底面粗度が側壁粗度よりも大きい場 合は内岸側循環流が横断面内で支配的となる.

このように側壁と底面の粗度が異なると二次流パター ンが大きく異なることが分かった．本研究では実験水路 の現象を対象としたが，今後は実河川も対象として蛇行 度と底面・側壁の状態の相互作用を検討していく。

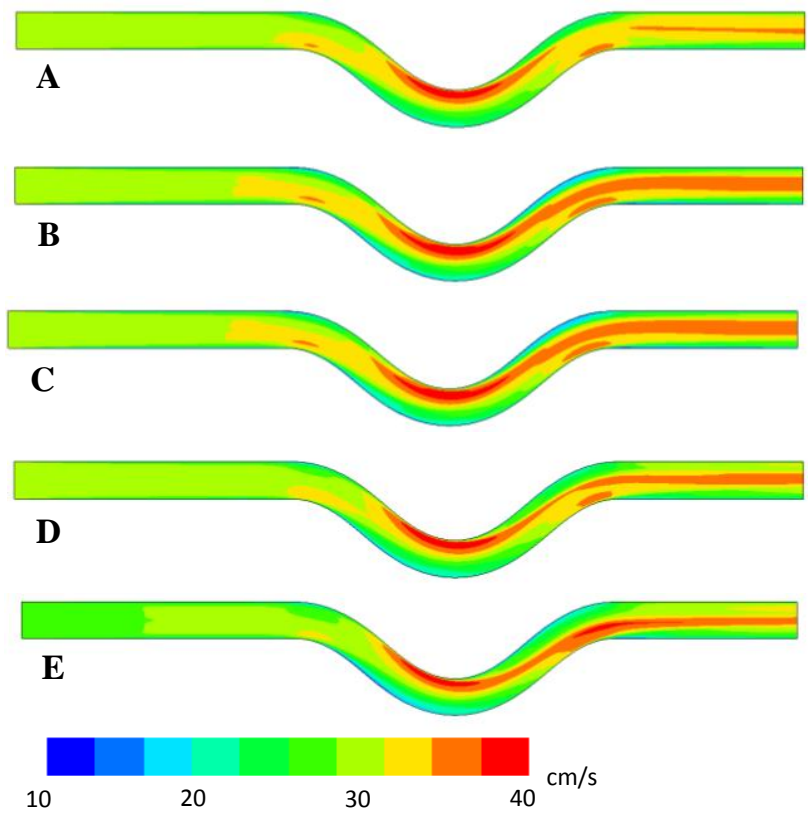

図-6 水深平均流速の平面図

\section{参考文献}

1) 鈴木理沙，木村一郎，清水康行 : 二次元・三次元RANSモデ ルによる開水路湾曲部における流況の再現性比較, 土木学会 論文集B1（水工学），Vol.71,No.4,pp.I_601-I_606,2015.

2) 福岡捷二 : 洪水の水理と河道の設計法, 森北出版, pp.296$309,2005$.

3) 杉山均, 秋山光, 砂糖亮輔 : 矩形断面蛇行開水路流れの三次 元乱流構造に関する研究，土木学会論文集 No.628/II-48, pp.149-161, 1999.

4)木村一郎： iRIC software Nays CUBE Tutorial, http://iric.org/ja/download/get/2D4TxH, 2015.

5) Naot, D.: Response of channel flow to roughness heterogeneity, $J$. Hydraulic Engineering, ASCE, Vol.111, pp.116-125, 1984.

6) Tominaga, A, Neze,I. : Three-dimensional turbulent structure in a straight open-channel flow with varying boundary roughness, Prc.of $3^{\text {rd }}$ Asian Congress of Fluid Mech.,pp.608-611,1986.

7) Hayashi, T.,Ohashi, M.,Kotani,Y.:River flow turbulence and longitudinal vortices, Recent Studies on Turbulent phenomena, Tokyo Inst. of.Tec. pp.243-295,1985.

8) 木村一郎, Wim S.J. Uijttewaal, 細田尚, Wim van Balen : RANSモデルによる開水路湾曲部における外岸セルの再現性, 水工学論文集, 第52巻, pp.1009-1014, 2008.

9) 滝本眞二, 木村一郎, 清水康彦, 細田尚 : 急な湾曲部を有す る開水路三次元乱流構造に関寸る数值シミュレーション, 応 用力学論文集, Vol.12,pp.749-758, 2009.

(2015. 9. 30受付) 